\title{
In-situ investigations on the echinoderm Asterias rubens as a predator of soft-bottom communities in the western Baltic Sea
}

\author{
K. Anger ${ }^{1}$, U. Rogal ${ }^{2}$, G. SChriever ${ }^{2} \&$ C. VALENTIN ${ }^{2}$ \\ ${ }^{1}$ Biologische Anstalt Helgoland (Meeresstation); Helgoland, \\ and \\ 2 Zoologisches Institut, Universität Kiel; \\ Kiel, Federal Republic of Germany
}

\begin{abstract}
In-situ investigations on the life of the common sea star (Asterias rubens L.) were carried out in 1976, employing the Underwater Laboratory "Helgoland" in Lübed Bay (Western Baltic Sea). The abundance of $A$. rubens amounted to $2-31 \mathrm{~m}^{2}$ on sediment (fine sand), and to 324-809 $\mathrm{m}^{-2}$ on mobile algal carpets drifting over the bottom. Actual population parameters (abundance, size class distribution) are influenced by both substrate quality and drifting. Stomach investigations revealed prey-size selectivity: Small sea stars feed mainly on the snail Hydrobia ulvae when living on the sediment, but on mussel brood (Myililus edulis) in the phytal. The principal food items of larger sea stars are the sand-dwelling clam Macoma baltica and the phytal-living isopod Idotea baltica respectively. A. rubens is very adaptive to the food available; the diversity of its diet corresponds to the species diversity found in its environment. A change of biotope during active or passive migrations causes switching. The sea star is able to catch motile animals and to dig out infaunal clams. It exhibits a diurnal feeding pattern related to light periodicity; the activity decreases at night. The average frequency of feeding is highly dependent on predator body size; it declines with growth. Insitu experiments indicate an exponential relationship between the feeding duration upon $M$. baltica and the quotient of clam size to logarithm of sea-star size. An approach is made toward a rough estimate of macrofauna consumption by $A$. rubens on sediment. The sea star seems to be an important predator and thus a competitor of demersal fishes on soft bottoms of the western Baltic Sea.
\end{abstract}

\section{INTRODUCTION}

The common sea star, Asterias rubens, is known within its distribution area as a frequent and voracious predator of mussel banks and other inshore epifaunal hardbottom communities. Although often found also on the wide fine-sandy and muddy bottoms of the western Baltic Sea (Kühlmorgen-Hille, 1965; Schulz, 1969; Arntz, 1971), its significance in this subsystem has not been investigated. Diving observations done by the authors in different parts of the bays of Kiel and Lübeck and in Danish waters during the period 1970-1975, suggest that the role of A. rubens as predator of 
soft-bottom communities of the western Baltic Sea is probably higher than assumed previously. In-situ investigations employing the Underwater Laboratory (UWL) "Helgoland" provid:d more detailed information. Saturation diving missions took place in June 17-30 (Rogal \& Valentin) and August 13-30, 1976 (Anger, Rogal \& Schriever) in Lübeck Bay.

\section{THE INVESTIGATION AREA}

The UWL was situated in the mission year 1976 at the geographical position $54^{\circ}$ $05.8^{\prime} \mathrm{N} / 10^{\circ} 55.2^{\prime} \mathrm{E}$ on sandy bottom at $15 \mathrm{~m}$ depth. The diameter of the investigation area, which was marked with ropes, amounted to ca. $160 \mathrm{~m}$. The water depth declined continuously from SE $(16 \mathrm{~m})$ to NW $(14 \mathrm{~m})$ and the sediment quality changed within

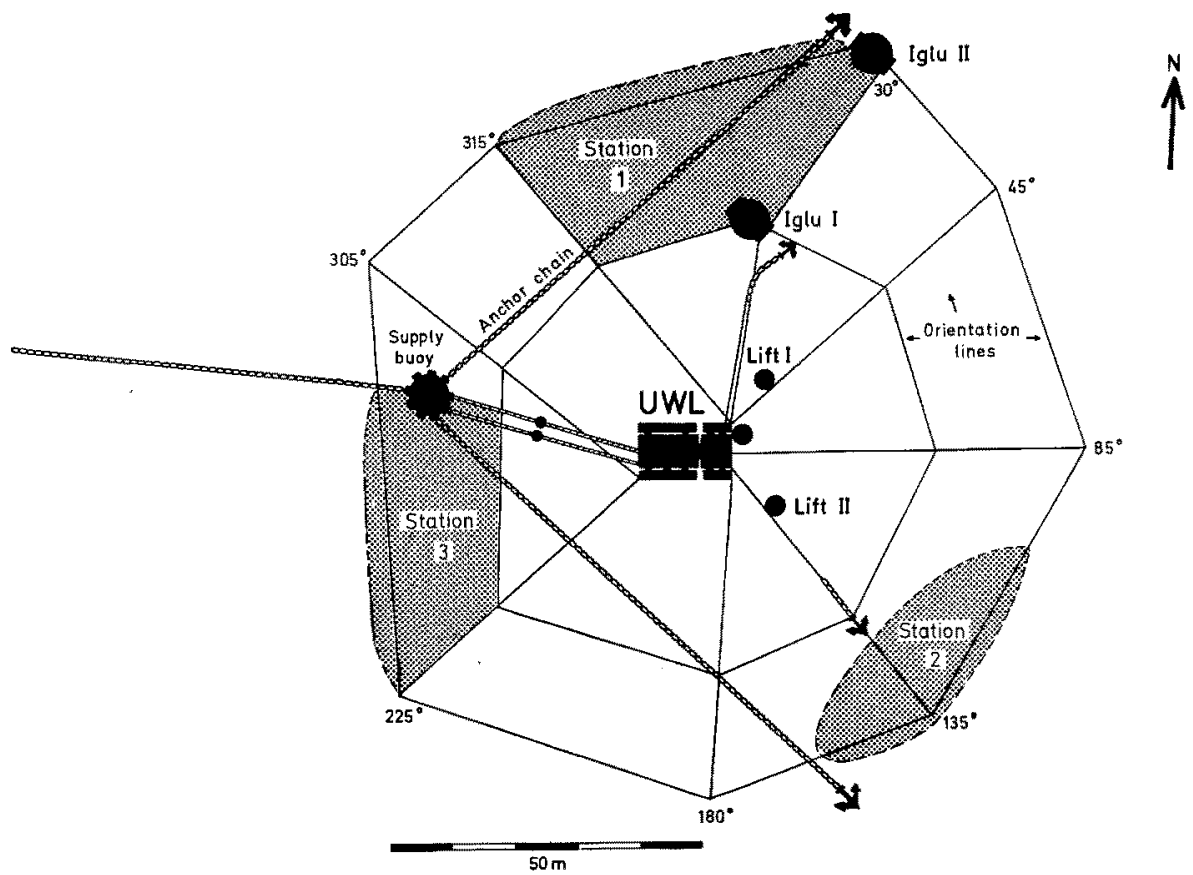

Fig. 1: The investigation area

the same gradient with decreasing mud content (more detailed sediment description in Rogal et al., in press). Three subareas at maximum possible distances from each other were selected as sampling stations (Fig. 1). Additionally, mobile phytal was investigated: a great amount of algae (survey of the species in Table 1), probably transported by bottom currents from shallower water, formed drifting meadows over the sea floor. Those carpets were about $5-10 \mathrm{~cm}$ thick and covered different size areas (a few to several thousand square metres). They drifted slowly over the sediment, covering about $50 \%$ of the total area. Their biomass consisted almost exclusively of 
Table 1

Algal species occurring in floating phytal

Cystoclonimm purpurascens

Phyllophora brodiaei

Ceramium arborescens

C. diaphanum

C. rubrum

C. strictum

Callithamnion corumbosum
Delesseria sanguinea

Pbycodrys sinuosa

Polysiphonia elongata

$P$. nigrescens

P. urceolata

P. violacea

Rbodomela confervoides

Polysiphonia nigrescens thalli, with a mean of $3741 \mathrm{~g}$ dry weight $/ \mathrm{m}^{2}$ (standard error in nine samples: $\left.\pm 299 \mathrm{~g} / \mathrm{m}^{2}\right)$.

\section{MATERIALS AND METHODS}

Sea-star biomass was determined after 4 months storage in buffered $4 \%$ formaldehyde solution. A possible diminuation of calcareous parts was not investigated. Comparing our results with those of Kowalski (1955), this source of error is regarded as not very important. Dry weight was determined after heating at $80^{\circ} \mathrm{C}$ to constant weight, ash-free dry weight after 3 -h ignition at $500^{\circ} \mathrm{C}$.

Phytal samples for the determination of sea-star abundance and size-class distribution were taken quantitatively by means of an air-operated suction sampler in $0.25-\mathrm{m}^{2}$ frames. The same gear, which is a modification of that described by the Finnish IBP-PM Group (1969), was also used to sample Macoma baltica for experimental purposes. The frames consisting of grey PVC were also useful for the determination of abundance, distribution pattern, and size-class distribution of Asterias rubens on the sediment surface. The sides of the frame measured $50-\mathrm{cm}$ long and $13-\mathrm{cm}$ high, having a cutting edge below. After a frame was carefully placed on the bottom, the sea stars within it were individually removed, measured, sorted into size classes (class width: $1.0 \mathrm{~cm}$ ) and recorded on a specially prepared writing board. Subsequently, the frame was displaced by its edge length and the process repeated. One mean value was obtained by pooling the data gained in this way from 21 to 224 frame contents depending on the abundance and thus, the amount of measurements performed. In the phytal, instead of this direct in-situ method, 10 repeated suction samples were taken (see above) and subsequently examined in the UWL. Thus a total of 1452 sea stars was counted, of which 972 were measured in situ in 1031 frame areas. Additionally, 2829 individuals of $A$. rubens were counted and 1798 measured in the UWL.

During the first mission some frames were equipped with nylon nets (mesh size: ca. $0.5 \mathrm{~cm}$ ) on their upper side to experiment with $A$, rubens feeding on undisturbed bottom fauna. The loss of macrofauna within a certain time period (several weeks) was to be estimated by means of control samples from the immediate neighbourhood of the experimental cages. This approach failed for two reasons: (1) The sea stars sit most of the time on the walls and the net instead of the bottom. (2) The nets were 
often clogged by drifting algae. Thus the natural situation was considerably changed and the experiment was terminated.

A second approach to estimating the feeding rate of the starfish was also of limited value for the same reason. In a plastic container $(40 \times 60 \times 21,5 \mathrm{~cm})$, which was also covered by a nylon net, one $A$. rubens (diameter: $7 \mathrm{~cm}$ ) was put together with 49 individuals of Macoma baltica scattered regularly in a thin sediment layer. This container was put between the runners of the habitat to be protected from drifting algae. At the end of the experiment, which ran from June 29 until August 8, the empty clam shells were counted.

Observations on the feeding activity pattern of $A$. rubens were made using the same method as applied for measuring population parameters on sediment: By first turning each individual and then applying slight pressure from the top side it was ascertained if the animal was feeding or not. After measuring the starfish, the result was noted as stroke or zero respectively in the column belonging to its size class. This study was carried out once for $48 \mathrm{~h}$, a second time for $24 \mathrm{~h}$ at intervals of $2 \mathrm{~h}$ at Station 1, whereby a total of 4922 individuals was examined.

At all three stations and in the phytal the stomach contents of 1039 individuals were studied in situ. They were revealed by the method described above, identified immediately and noted after measuring the diameter of the starfish. The size of the prey species was also recorded in all cases where it was possible.

It was often observed that A. rubens, if severely disturbed, released its prey from its arms and even from its stomach. Thus, other methods, unlike in-situ observations (e.g. sampling by means of a dredge etc.), could never be as successful.

Finally, experiments on the feeding time of A. rubens upon Macoma baltica were carried out. The first approach in flow-through aquaria, mounted within the habitat failed owing to the "wall effects" described above. Therefore, the following in-situ experiments were accomplished: Numbered open petri dishes with just sampled, undamaged $M$. baltica were put on horizontal platforms in front of two large portholes. Subsequently, sea stars of different sizes, which were not feeding when being sampled, were put onto the platforms. The experiments could be observed from inside the habitat. When a starfish got into feeding position over a clam and began to pull at the shell parts (this behaviour was also controlled from beneath by turning the petri dish carefully), this time was noted as start of feeding. Neighbouring $A$. rubens, which might have disturbed the feeding process as competitors, were removed. The end of feeding was normally conspicuously marked by a sudden relaxing and subsequent moving of the starfish. The diameter of the predator and the length of the empty clam shell were immediately measured and noted together with the time. If there was no clear feeding end or if the clam meat was not ingested totally, this experiment was disregarded. A total of 60 valid data on feeding time for different size ratios of A. rubens and M. baltica was obtained in this way. 


\section{RESULTS}

Biomass, abundance, and size-class distribution

Dry weight and ash-free dry weight were determined for 68 Asterias rubens of different sizes, taken from a random sample. The regressions are given in Figures 2 and 3. Figure 4 reveals that the percentage of organic substance (expressed as ash-free dry weight) scatters strongly, but a trend of increase with growth is obvious. Therefore, the regression lines in Figures 2 and 3 are not parallel, but convergent. This indicates a decreasing growth rate of the skeleton in relation to the soft parts (namely the gonads).

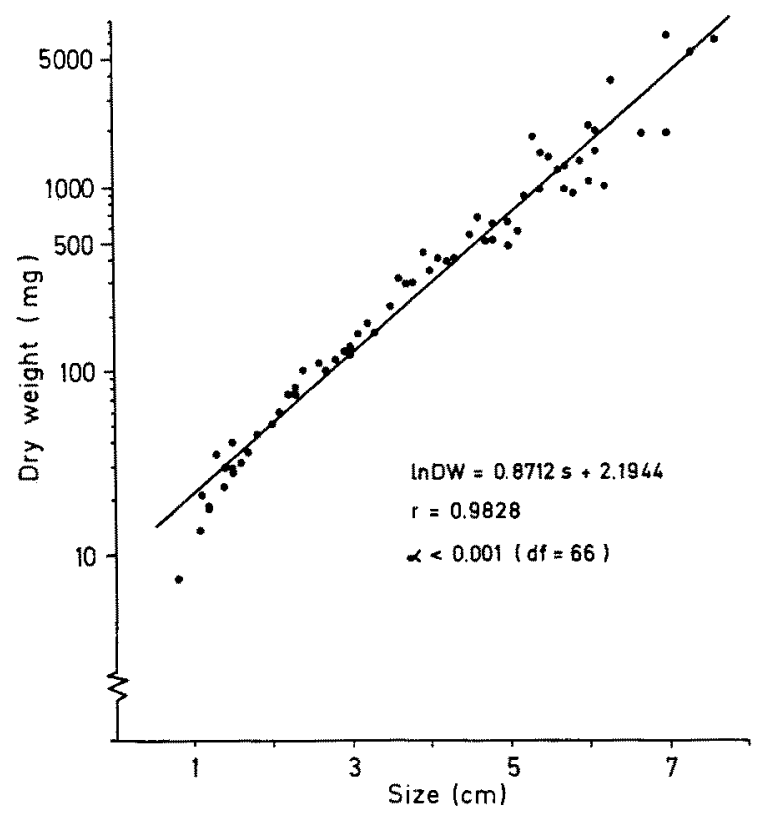

Fig. 2: Asterias rubens: Dry weight (DW) in relation to body size (diameter)

Tables 2 and 3 summarize the measurements of population structure of $A$. rubens. The abundance values (Table 2) remained almost constant in June, but fluctuated in August. Among the sediments mostly the deeper, muddier Station 2 harboured the densest population, on an average consisting of smaller individuals (cf. Table 3). On August 27 and 28 heavy wave action caused strong water movements near the bottom. In this situation $A$. rubens becomes unable to hold on to the aufwuchs-free sediment and drifts with bottom current. The records of August 28 reveal notable change of population density (Table 2).

The drifting phytal carpets were always crowded most densely. The mean individual size was conspicuously smaller here than on sediment. Although a consider- 
able growth must be expected in summer (for literature review see Feder \& MøllerChristensen, 1966), it cannot be derived from size-class distribution (Table 3).

From the abundance values (Table 2), size-class distribution (Table 3) and the regression equations (Fig. 3), biomass values can be calculated for the sea-star population. In Table 4 they are given as ash-free dry weight and - using the data of Kowalski (1955) - as wet weight (in parentheses).

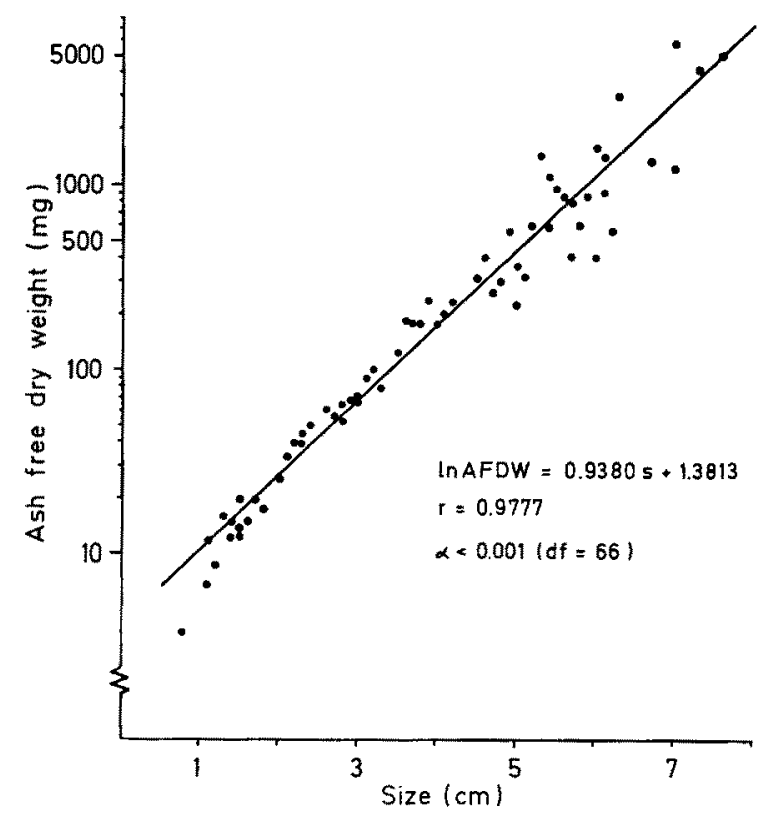

Fig. 3: Asterias rubens: Ash-free dry weight (AFDW) in relation to body size (diameter)

\section{Feeding activity rhythm}

From August 17-19 and 26-27 at Station 1 the feeding activity of Asterias rubens was investigated at 2 -h intervals, examining at least 100 individuals for each value $(\mathrm{N}=106-176)$. During this total period of $72 \mathrm{~h}, 4922$ observations were recorded, allowing conclusions on a feeding activity rhythm (Fig. 5). The material on the sizes classes $<2 \mathrm{~cm}$ and $>5 \mathrm{~cm}$ is too small and does not show any obvious trend. All information on the other size groups indicates a diurnal rhythm with decreased feeding activity at night.

In the morning of August 27 (arrow in Fig. 5 at 10 h) the strong water movement mentioned above set in. It loosened the sea stars from their substrate and transported them over the bottom. The percentage of feeding $A$. rubens declined from this time on as can be expected. The observation was stopped after $24 \mathrm{~h}$ because of this perturbation in the natural activity pattern. 
Investigations on Asterias rubens
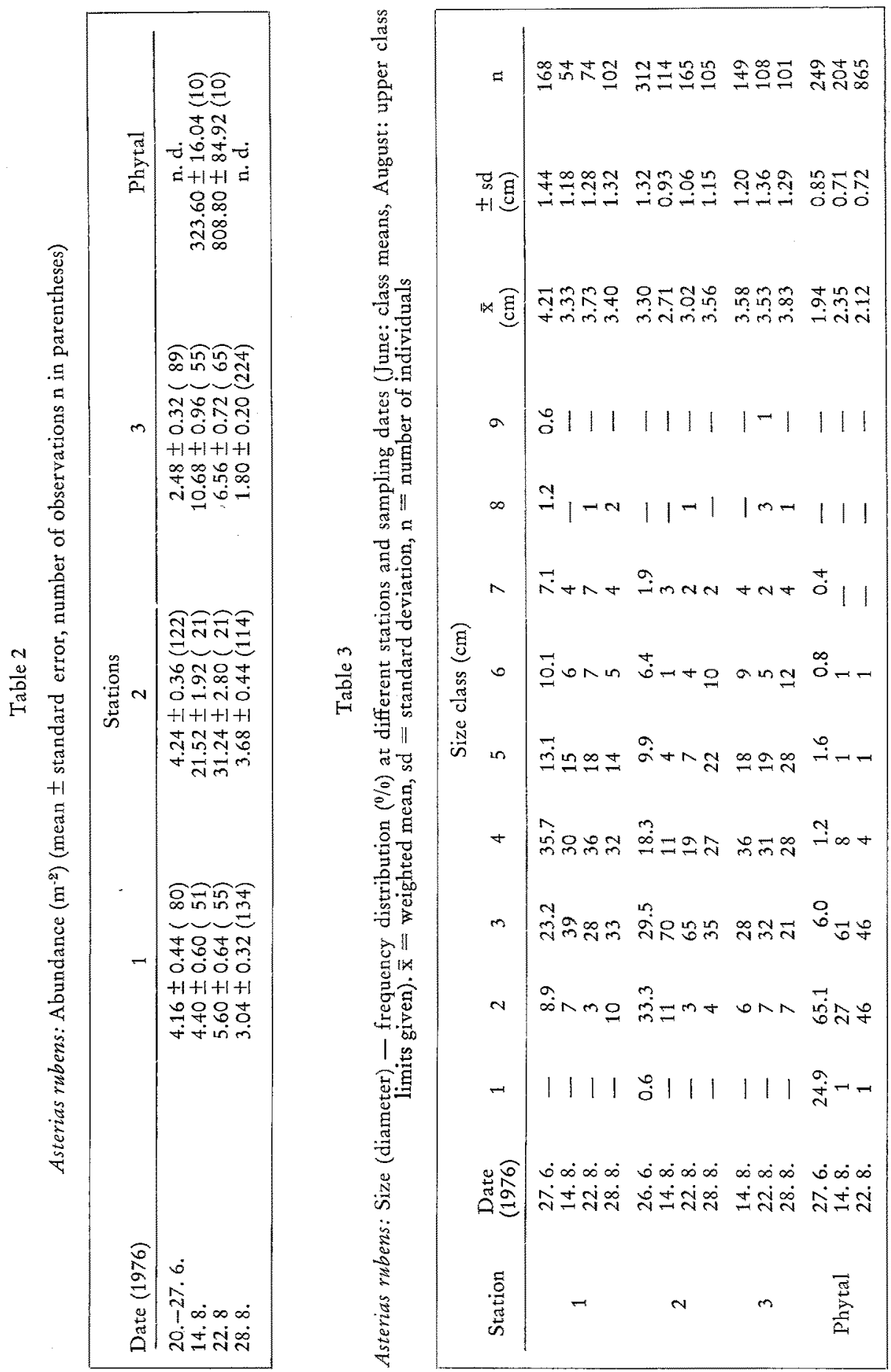
Table 4

Asterias rubens: Biomass $\left(\mathrm{gm}^{-2}\right)$, calculated as ash-free dry weight and wet weight (in parantheses)

\begin{tabular}{|rcccc|}
\hline $\begin{array}{c}\text { Date } \\
(1976)\end{array}$ & 1 & 2 & 3 & Phytal \\
\hline $26 .-27.6$. & $0.9(14.6)$ & $0.4(6.3)$ & n.d. & n.d. \\
14.8. & $0.4(6.7)$ & $1.1(18.4)$ & $1.2(20.7)$ & $11.7(197.8)$ \\
22.8. & $0.7(12.5)$ & $2.1(35.8)$ & $0.7(12.3)$ & $23.5(398.5)$ \\
28.8. & $0.3(5.0)$ & $0.4(7.0)$ & $0.3(4.4)$ & n.d. \\
\hline
\end{tabular}

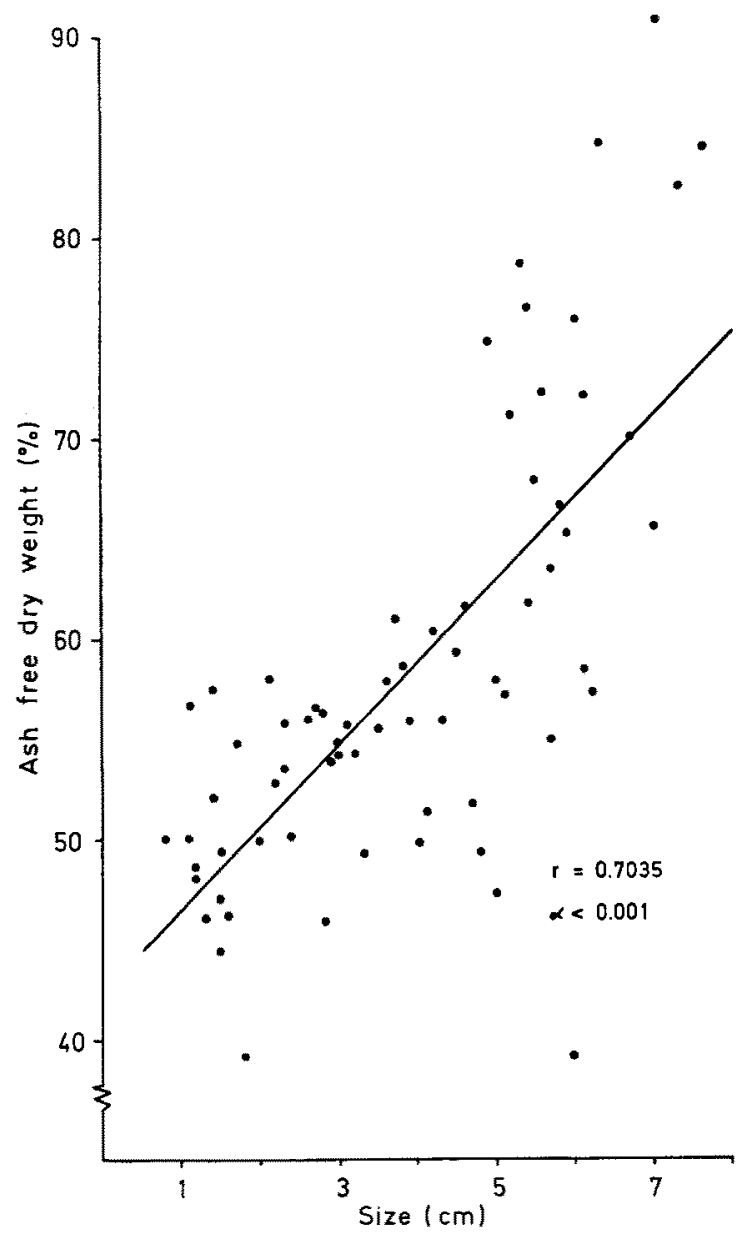

Fig. 4: Asterias rubens: Organic substance (expressed as ash-free dry weight) percentage of total dry weight in relation to body size (diameter) 

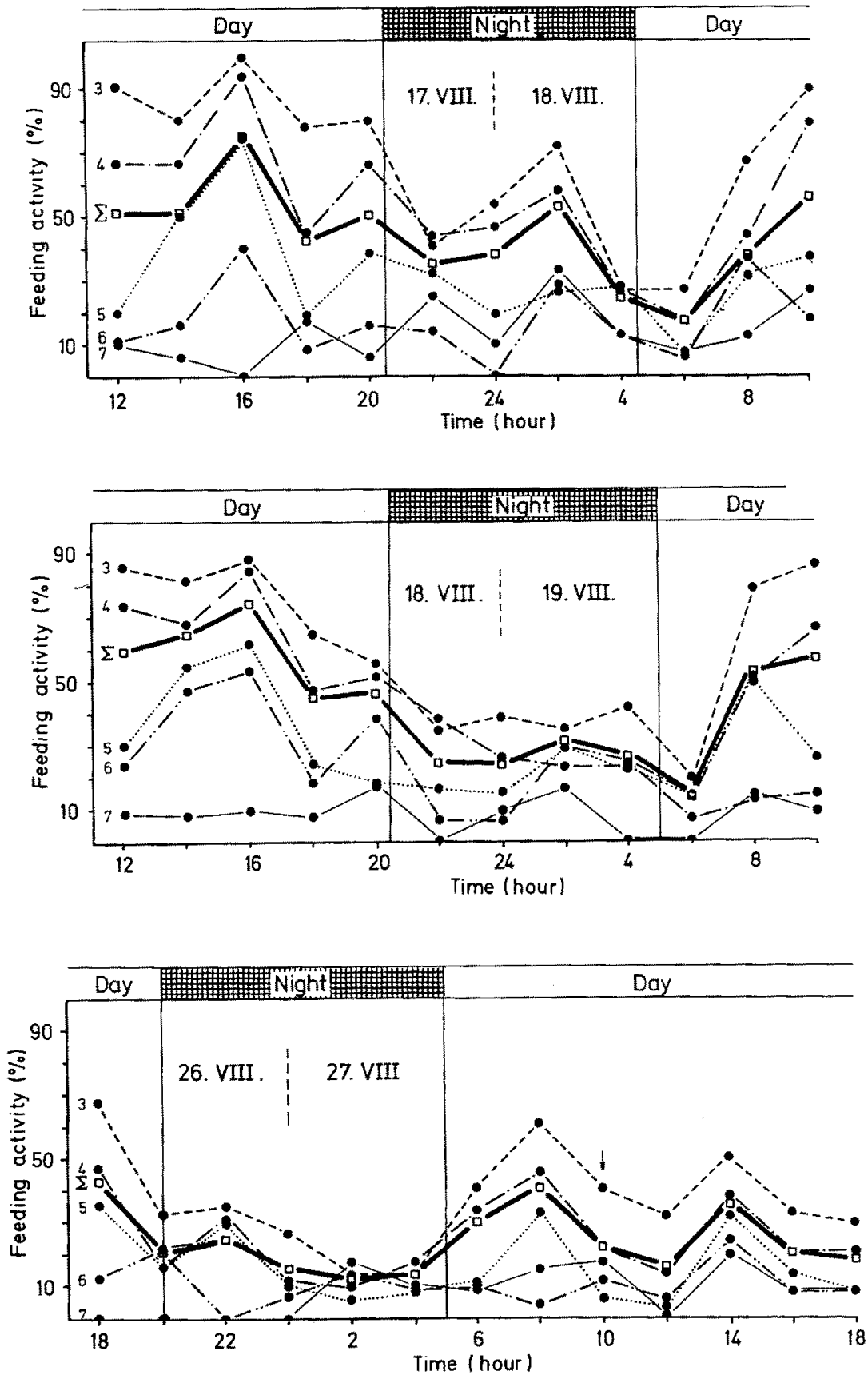

Fig. 5: Asterias rubens: Feeding activity (expressed as percentage feeding individuals). The numbers above the curves mark the upper limits of size classes $(\mathrm{cm}), \Sigma$ the population average 
Figure 5 furthermore indicates that smaller individuals are encountered feeding much more frequently than larger ones. The percentage frequency found for the different size classes was calculated for the first undisturbed 48 -h period and given in Figure 6 as daily average.

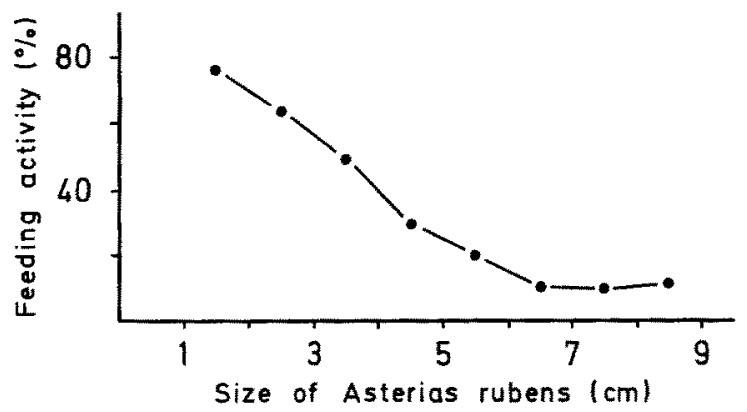

Fig. 6: Asterias rubens: Feeding activity (daily mean on August 17-19) in relation to body size (diameter)

\section{Stomach contents}

In June, 201 feeding individuals of Asterias rubens were examined as to their stomach contents. The following food was found: Hydrobia ulvae (in 149 sea stars), Macoma baltica, fish faeces (each in 9), Pectinaria koreni (in 7), juvenile Mytilus edulis (in 6). Mysella bidentata, Asterias rubens (each in 3), Astarte spec., Idotea baltica, Diastylis ratbkei, undet. Amphipoda, Corbula gibba, undet. Insecta (each in 2), Mya arenaria, Balanus spec., undet. Mysidacea (each in 1).

This first survey left the impression that different size groups of $A$. rubens obviously have different food preferences. Therefore, in August at daytime (cf. Fig. 5) the stomach contents of a further 938 feeding individuals were analysed separately by size class and station (Table 5 ). These investigations provided evidence that the food spectrum includes not only many benthic species, among them several highly motile forms, but also fish faeces and dead terrigenous material (flies, beetles etc.). The natural abundance of the most important food animals in the investigation area is given in Table 6. A more detailed description of the macrofauna and of the methods used to examine it is being published by Rogal et al. (in press). The frequency of occurrence of what was found in stomachs of feeding $A$. rubens is given in Figure 7. The four most prominent food species and the sum of less important items ("miscellaneous"), as far as at least 10 observations per" value were available, are given. This information is presented separately for all the size groups of sea stars, where enough data could be provided (cf. Table 5).

The small snail Hydrobia ulvae is of the greatest importance to juvenile sea stars. The frequency of its occurrence in stomach contents declines drastically with the increasing body size of the predator (Fig. 7). If a large sea star ingests hydrobiids, then it usually takes several individuals at once or in short succession. The mean individual 


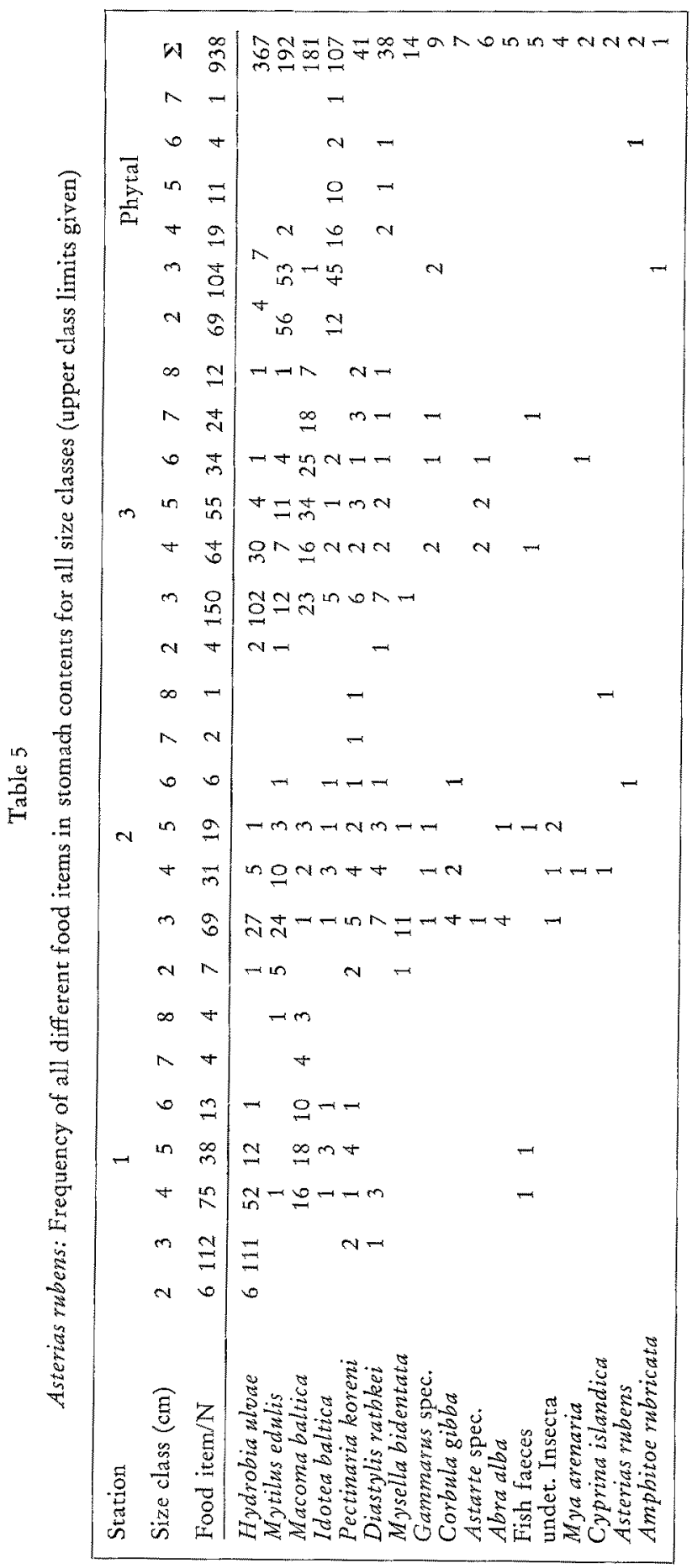


Table 6

Mean abundance $\left(\mathrm{m}^{-2}\right)$ of the most prominent macrobenthic food species in August 1976

\begin{tabular}{|c|c|c|c|c|}
\hline \multicolumn{5}{|c|}{ Stations } \\
\hline Species & 1 & 2 & 3 & Phytal \\
\hline $\begin{array}{l}\text { Hydrobia ulvae } \\
\text { Mytilus edulis }\end{array}$ & 1635 & $\begin{array}{l}102 \\
134\end{array}$ & 1721 & 204 \\
\hline & $14 \overline{70}$ & 134 & $\begin{array}{r}31 \\
1548\end{array}$ & 224080 \\
\hline Idotea baltica & - & 220 & 1548 & $53 \overline{18}$ \\
\hline Pectinaria koreni & 141 & 440 & 605 & 3010 \\
\hline Diastylis ratbkei & 55 & 1061 & 126 & - \\
\hline
\end{tabular}

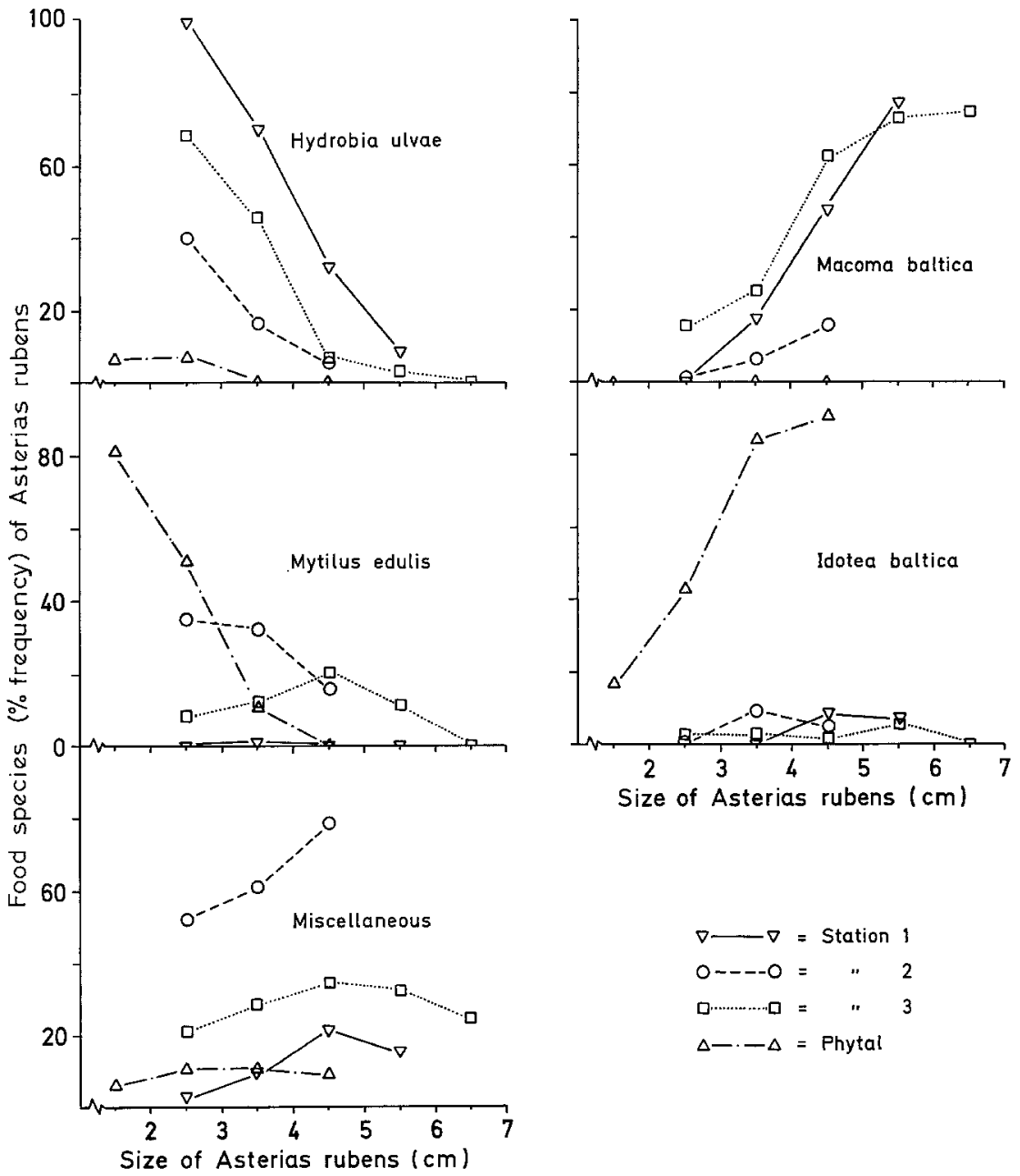

Fig. 7: Asterias rubens: Percentage frequency of the main food items in stomach contents 
Table 7

Asterias rubens: Mean individual number ( \pm standard error) of Hydrobia ulvae per stomach (zero values excluded) relative to sea-star body size

\begin{tabular}{|lcccc|}
\hline Size class $(\mathrm{cm})$ & 2 & 3 & 4 & 5 \\
\hline Number of hydrobiids & 1.67 & 2.29 & 2.15 & 2.92 \\
& \pm 0.42 & \pm 0.12 & \pm 0.14 & \pm 0.61 \\
\hline $\mathrm{n}$ & 6 & 111 & 52 & 12 \\
\hline
\end{tabular}

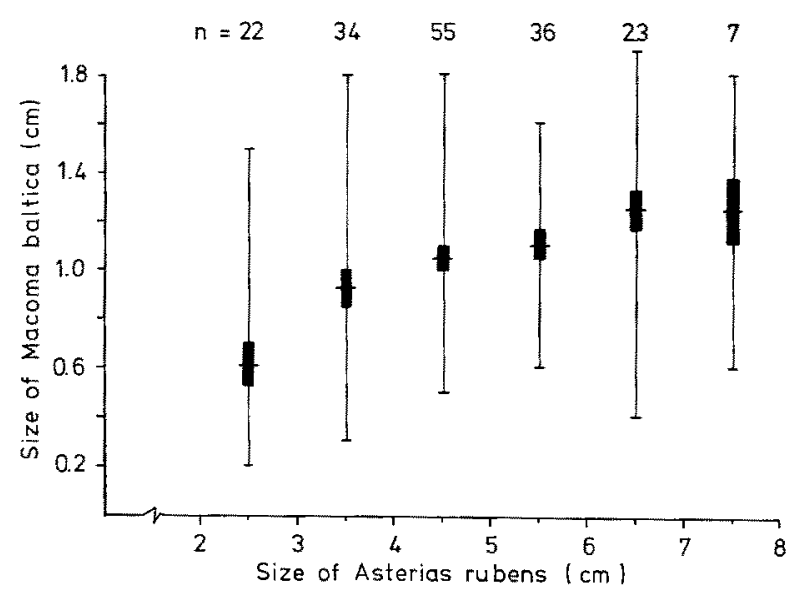

Fig. 8: Asterias rubens: Shell length of consumed Macoma baltica in relation to sea-star body size. Mean value, standard error and range given in the graph, number of observations ( $n$ ) above

number of snails per stomach is given for different size groups of $A$. rubens in Table 7. There is also a difference in frequency of being eaten among the stations: On the sediment, particularly at the sandy Stations 1 and 3, H. ulvae was discovered much more frequently in sea-star stomachs than on the phytal (Fig. 7).

Juvenile Mytilus edulis of mostly 1-2 mm shell length played the same role on the algal carpets in August as $H$. ulvae did on the sediments. Young mussels were found remarkably frequently outside the phytal only at muddy Station 2.

In Macoma baltica there is an opposite trend. Young A. rubens feed on clams relatively seldom, but older (larger) ones very often do. A comparison of the stations in Figure 7 reflects the food supply well (Table 6). As $A$. rubens with increasing size ingests higher numbers of snails contemporarily, it prefers also larger sized $M$. baltica (Fig. 8). This is also true in the phytal biotope for the isopod Idotea baltica (Fig. 9), which has hardly any importance on the sediment (cf. Tables 5 and 6).

The shapes of the graphs for "miscellaneous" (Fig. 7) indicate that larger sea stars have a wider food spectrum than smaller ones. The food diversity is highest at Station 2, lowest in phytal. The most important among the miscellaneous species are the 


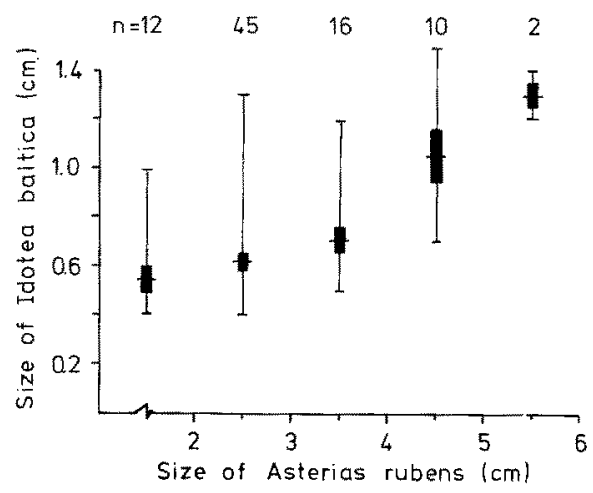

Fig. 9: Asterias rubens: Body length of consumed ldotea baltica in relation to sea-star body size (for further explanation c. f. Fig. 8)

polychete Pectinaria koreni and the cumacean Diastylis rathkei. Both reach their highest abundance at Stations 2 and 3 (Table 6) and thus have their highest significance there as food items of $A$. rubens.

\section{Feeding behaviour}

The fact that a considerable proportion of sea-star diet consists of motile, rather fast swimming animals (Idotea baltica) is due to the ability of A. rubens to catch prey by means of the suction force of its ambulacral feet. This can happen quickly, and without the prey realizing it at first. The caught animal (isopod or amphipod) is held fast by two opposite sea-star arms and then is slowly transported by the tubuli to the mouth. Large prey individuals often remain alive and partly ingested for a rather long time.

To reach infaunal sediment dwellers like Macoma baltica, Diastylis ratbkei, or Pectinaria koreni, the sea star digs a hole using mostly the central parts of its body and to a slight extend its arms (Fig. 10). The prey is pulled up by perioral tubuli and digested in this position.

Smaller food organisms (juvenile Mytilus edulis, Hydrobia ulvae, Mysella bidentata, juvenile Idotea baltica and Pectinaria koreni) are digested intraorally. Even larger animals ( $M$. baltica, adult $I$. baltica and $P$. koreni) are often at least partly ingested. A purely extraoral digestion was observed only for very large sized food (fish faeces, carrion, Mya arenaria, Cyprina islandica).

\section{Feeding timeon Macoma baltica}

In the plastic container experiment described above, a starfish (diameter: $7 \mathrm{~cm}$ ) fed on 33 of $49 \mathrm{M}$. baltica (mean length: $13.5 \mathrm{~mm}$; standard deviation of the mean: $\pm 2.1 \mathrm{~mm}$ ) within 51 days. The clams which were not eaten in this time had a mean 


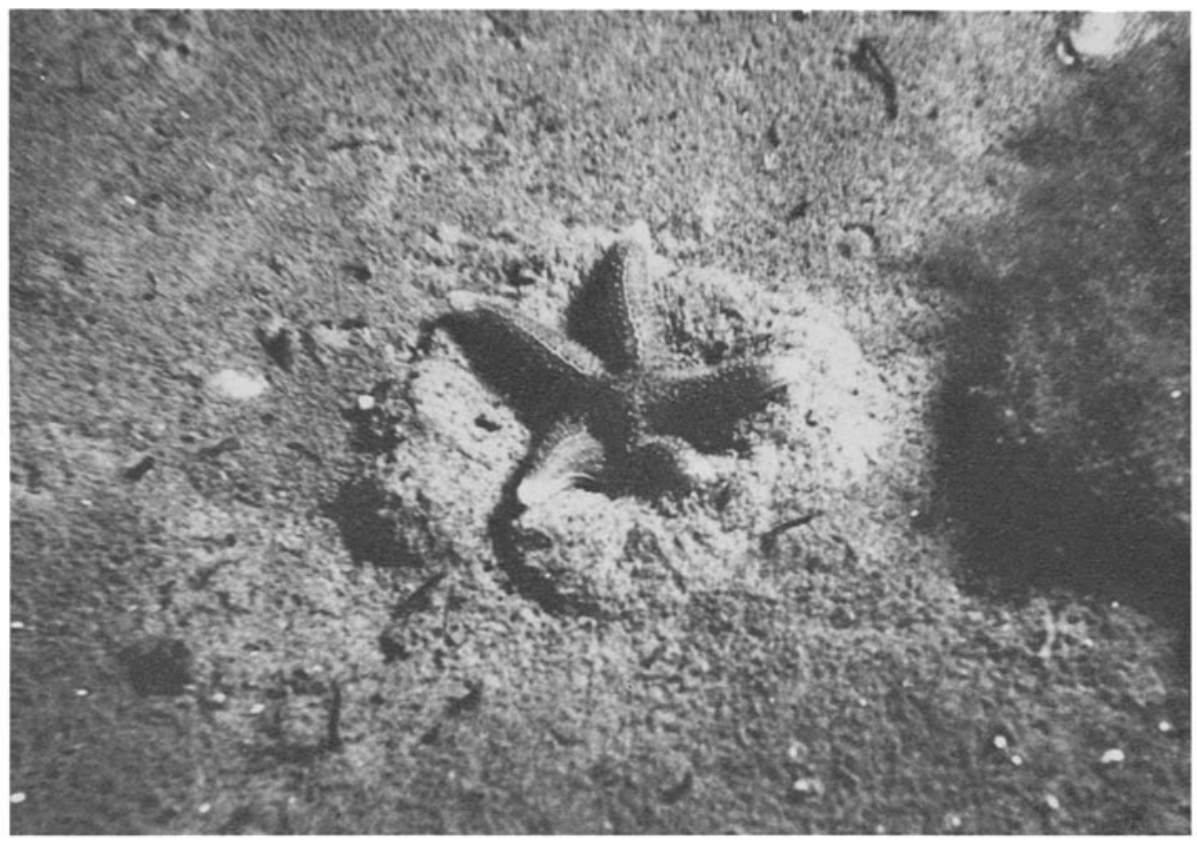

Fig. 10: Asterias rubens digging for Macoma baltica. (Photo: Valentin)

size of $12.4 \pm 0.4 \mathrm{~mm}$. This result also indicated a food-size selection as was revealed by our in situ stomach analyses. The average feeding rate in this experiment amounted to 0.65 individuals $(M$. baltica) of the given size per day.

The maximum possible feeding rate on $M$. baltica can be derived from the individual feeding time, which was determined in 60 in-situ experiments. From these a statistical relationship was calculated describing the dependence of feeding time on the predator-prey size ratio (Fig. 11). The time span varied from $40 \mathrm{~min}$. to $10.5 \mathrm{~h}$. Theoretical feeding time curves for different sea-star size classes and variable clam size were derived from the regression equation (Fig. 12). They indicate that the feeding time is almost independent of the sea-star size if very small clams are fed on, but is increasingly correlated to it with increasing shell length.

\section{CONCLUSIONS AND DISCUSSION}

Previous investigations on the life of sea stars were mostly accomplished in aquaria, some in the tidal zone. The present experiments and observations revealed that Asterias rubens may behave quite differently under laboratory and natural conditions as aquarium walls stimulate climbing, offered food is often refused, and a too low flow rate causes mortality. Stomach analyses after sampling (e.g. dredging) are also hard to interpret because of frequent food release as a stress response. The relia- 
bility of feeding experiments under laboratory conditions is uncertain as well. The influence of bad weather situations on distribution and behaviour is hard to observe even for divers coming from the surface. These facts underline the excellent suitability of the saturation diving method for the study of many important problems in marine biology.

The populations of sea stars show strong fluctuations of abundance and size-class distribution, caused mainly by currents. As was also shown by diving investigations by Brun (1968), long term studies at fixed stations are always subject to error, particularly concerning growth measurements, because different populations are treated during that time. Growth rate calculations upon size-class distributions are not possible for $A$. rubens for the reason that different nutrition and other environmental factors cause strong fluctuations in body size within a single age group (Bull, 1934; Hancock, 1958).

A passive drifting, in particular of juvenile $A$. rubens, was noted on the mobile phytal and during bad weather situations also on sediments. Active migration can also be assumed from our numerous diving observations in the western Baltic Sea. Direct settlement on soft bottom must be excluded, since the youngest benthic stages are always missing there. $A$. rubens is the only echinoderm whose larvae are known to react with positive phototaxis during their total pelagic phase of several weeks (Thorson, 1964). Therefore, they settle exclusively on hard bottoms and phytal in shallow water, prolonging their planktonic life if suitable substrate cannot be found (Thorson, 1957). The early benthic stages feed mainly on mussel brood settling at about the same time.

A considerable part of the sea-star population becomes transported by drifting algae during the summer into deeper zones. On the phytal carpets a dense growth of young Mytilus edulis is available as suitable food for small sea-star individuals, the

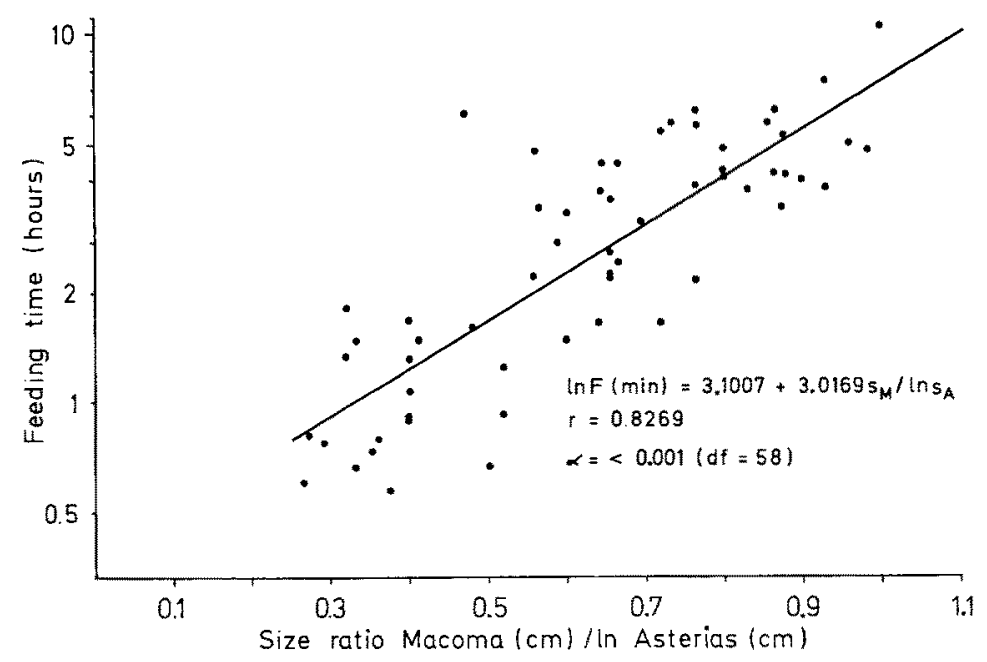

Fig. 11: Relation between feeding duration, F (min), and the quotient of clam size, sM $(\mathrm{cm})$, to logarithm of sea-star diameter, $\mathrm{sA}_{\mathrm{A}}(\mathrm{cm})$ 
frequent isopod Idoted baltica for larger ones. As could often be observed, many growing sea stars leave this biotope and thus become sediment dwellers. The new substrate with its differently constituted pool of prey organisms forces an immediate switching: Hydrobia ulvae is taken instead of young mussels, Macoma baltica instead of isopods as main food items.

Stomach analyses revealed that $A$. rubens exhibits a conspicuous prey-size preference, mainly limited by the arm strength (Figs 7-9). $M$. baltica, for example, occurred predominantly in a juvenile stage of $3-4 \mathrm{~mm}$ shell length in the sediment (Rogal et al., in press), but mainly much larger individuals were eaten (Fig. 8). This fact is surprising in so far as larger clams are buried deeper in the sediment and thus, are harder to obtain.

Except regarding body size, a qualitative food species selection obviously does not exist. The stomach contents of $A$. rubens agree well with the food supply in the biotope, the width of its spectrum corresponds with the diversity $\left(\mathrm{H}^{\prime}\right)$ and evenness $\left(J^{\prime}\right)$ of the macrofauna (cf. Rogal et al., in press). Since larger sea-stars are not as

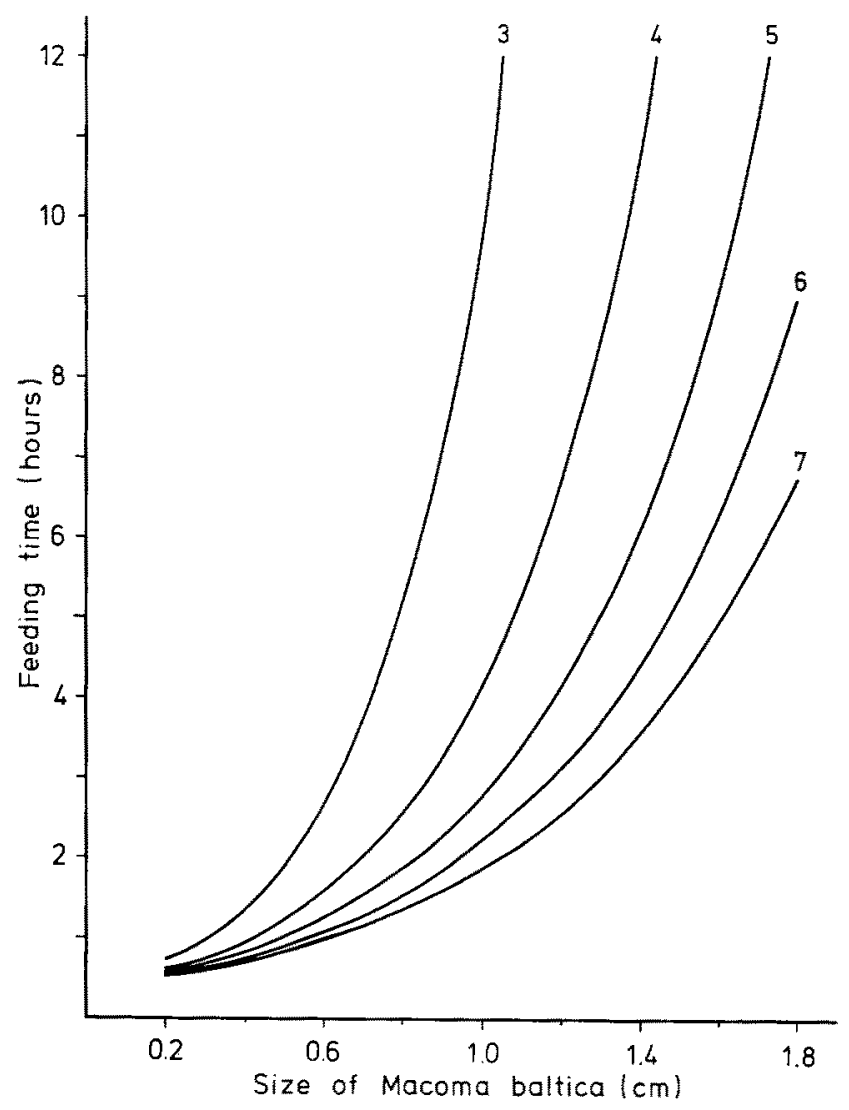

Fig. 12: Asterias rubents: Theoretical feeding duration (h) for several sea-star size classes (upper class limits given above the curves in $\mathrm{cm}$ ) in relation to clam size $(\mathrm{cm})$ 
dependent on a maximum prey size as smaller ones, they are able to ingest a wider selection of food items. Thus, food selectivity becomes weaker with increasing growth of sea stars.

A. rubens is very adaptable not only to the quality of its prey but also in its predation behaviour: Motile phytal dwellers (e.g. Idotea baltica) are held fast and eaten when accidentally touched by arm tubuli. Very small animals (e.g. Hydrobia ulvae, juvenile Mytilus edulis) are simply collected and ingested totally. Prey living buried in the sediment (e.g. Macoma baltica) is dug out mainly by the action of the central tubuli.

The digging behaviour requires a prior chemoreception of the prey through the respiratory water current. The latter ability had been suggested by Spärck (1932) from observations of directed food migrations and by Bull (1934) from aquarium studies. Also for A. vulgaris (according to Tortonese, 1963, synonymous with A. rubens) there are similar observations (Smith, 1940). Loosanoff (1958) described the digestion of $V$ enus mercenaria by $A$. forbesi in the sediment whereby the stomach is extended into the siphon opening.

A. rubens also engages in cannibalism. On sediments in the investigation area this phenomenon was observed only twice, in the phytal, however, rather frequently. It occurs also often in mussel beds near Surendorf (Kiel Bay) and on the surrounding sand flats, which are crowded with sea stars which have fallen down from (artificial) rocky walls, but are poor with respect to food animals. When a great number of $A$, rubens sits on carrion meat (fish, Carcinus maenas etc.) it can very often be observed that some of them digest each other beginning from the arm tips. Thus, cannibalism generally occurs in high frequency, if population density becomes extremely high, and particularly if hunger or certain chemical stimuli are involved.

The feeding activity rhythm is obviously governed by the daily light periodicity. Light perception is accomplished by eye spots and dermal light sensitivity (Yoshida, 1966). The biological basis of this behaviour pattern is not clear.

The feeding rate of the sea star is maximum at $10-13^{\circ} \mathrm{C}$, above and below which it declines (Hancock, 1958). This means that our investigations were accomplished under optimum conditions. Thus it is possible that the perturbation of the activity pattern by wave-caused water movements (August 27) was affected not only mechanically, but also by collapse of the thermocline and the subsequent warming up to $16-18^{\circ} \mathrm{C}$.

A decreasing average feeding activity with increasing sea-star body size as observed by us can also be concluded from Hancock's (1955) data. Hatanaka \& Kosaka (1959) made identical observations in A. amurensis. This fact corresponds to the general law of decreasing metabolism with increasing body mass. Larger sea-star individuals feed on larger prey and at longer intervals. Our value of ca. $10 \%$ mean feeding activity for large $A$. rubens agrees with diving observations by Brun (1968).

The statistical relationship derived from our feeding experiments with Macoma baltica (Fig. 12) shows that very small clams are eaten in a short time, almost independently of sea-star size. This can be explained by the mechanism of intraoral digestion as a physiological constant. The larger the clam is, the more the time to open the shell (i. e. the pulling force of the sea star) plays an important role; digestion becomes in- 
creasingly extraoral and the feeding time is prolonged considerably with decreasing sea-star size. Under totally natural conditions, the digging time, which was excluded in the experiment, must be regarded. According to some preliminary observations it is presumed to be in the same order of magnitude as the pure feeding time. It can be hypothesized, because of the relation shown above, that there is a maximum acceptable clam size for each size of $A$. rubens, above which the muscle force is insufficient to open the shells or the feeding process becomes so long that it leads to energy loss. The longest observed feeding time of about $10.5 \mathrm{~h}$ could tend towards this upper limit. The respective maximum clam sizes resulting from this time agree well with the extreme values observed in stomachs of individual sea stars. Thus, besides a purely mechanical, an energetic basis of prey-size selectivity is to be supposed as well. However, there is an exception to this rule: Sometimes it can be observed that a whole group of sea stars unites successfully to open a very large shell (namely Cyprina islandica). Since the predator specimens alternate and the opening time fluctuates greatly according to number and size of sea stars, this cooperative predation process cannot be described accurately. Usually, size-limited predation is to be regarded as the normal case in A. rubens. It was also described by Paine (1976) for the Mytilus californianus Pisaster ochraceus interaction. Such limitation is assumed to be significant for the coexistence of prey and predator in intimate proximity.

From the data on population structure and feeding behaviour pattern, the consumption of macrofauna by $A$. nubers can be estimated roughly for Station 1 . This value is valid only for the temperature of the investigation period $\left(12^{\circ} \mathrm{C}\right)$, because the activity is highly dependent on it. Reliable feeding time data are available only for $M$. baltica. For $H$. ulvae it was estimated after preliminary experiments as $1 \mathrm{~h}$ per snail (regardless of sea-star size and snail number per stomach). Moreover it is still unclear, if all snails in a sea-star stomach are actually digested. For fishes this is not the case (Muus, 1967). Such a rough estimate could be done as follows:

$$
\begin{gathered}
C=\sum_{s}^{i=1} \sum_{s}^{j=2} \bar{b}_{i j} \cdot q_{i j} \cdot \bar{m}_{i j} \cdot \bar{a} \cdot p_{j} \cdot f_{j} \cdot \frac{1}{\overline{t_{i j}}} \\
{\left[m g \cdot m^{-2} \cdot \text { day }^{-1}\right]}
\end{gathered}
$$

where:

$\mathrm{C}=$ consumption,

$\overline{\mathrm{b}}_{\mathrm{ij}}=$ mean individual biomass of the $\mathrm{i}-\mathrm{th}$ prey species having the body size preferred by the $j$-th size group of $A$, rubens,

$\mathrm{q}_{i j}=$ relative frequency of the $i$-th prey species within the diet of the $j$-th size group of $A$. rubens,

$\overrightarrow{\mathrm{m}_{\mathrm{ij}}}=$ mean number of individuals of the $i$-th prey species per stomach of sea star (size group j) (exclusively zero values),

$\overline{\mathrm{a}}=$ mean abundance of the total sea-star population $\mathrm{m}^{-2}$,

$\mathrm{p}_{\mathrm{j}}=$ numerical portion of the $\mathrm{j}$-th size group in the total sea-star population,

$\mathrm{f}_{j}=$ portion of feeding A. rabens (daily mean) within the $\mathrm{j}$-th size group,

$\overline{\mathrm{t}_{\mathrm{ij}}}=$ mean feeding time of $A$. rubens ( $\mathrm{j}$-th size group) on the $\mathrm{i}$-th prey species (expressed in days),

$\mathrm{s}=$ number of prey species 
Table 8

Asterias rubens: Estimated individual daily uptake of Hydrobia ulvae (HU) and Macoma baltica (MB). Ind, = mean individual number; OS = mean organic substance (mg); $\% \mathrm{BW}=$ uptake as percentage of sea-star body weight (ash-free dry weight). Size groups upper class limits given $(\mathrm{cm})$. Total $=$ Population at Station 1 (August mean)

\begin{tabular}{|lcccccc|}
\hline $\begin{array}{c}\text { Organisms } \\
\text { fed }\end{array}$ & 2 & \multicolumn{7}{c}{ Size classes of Asterias rubens } & Total $\left(\mathrm{m}^{-2}\right)$ \\
\hline HU (Ind) & 31 & 35 & 17 & 6 & 1 & 102 \\
HU (OS) & 1.8 & 2.1 & 1.0 & 0.4 & 0.1 & 6.1 \\
MB (Ind) & - & - & 0.7 & 1.1 & 1.4 & 2.4 \\
MB (OS) & - & - & 4.3 & 8.8 & 13.1 & 17.4 \\
$\sum$ OS & 1.8 & 2.1 & 5.3 & 9.2 & 13.2 & 23.5 \\
\% BW & 11.4 & 8.3 & 5.0 & 3.4 & 1.9 & \\
\hline
\end{tabular}

Regarding only the loss of the two principal prey species (M. baltica and $H$. wlvae), which constituted $92 \%$ of all stomach contents at Station 1 , the estimates given in Table 8 can be derived by the above formula. The ash-free dry weight values of these molluscs are estimated (from unpublished results of Wiek \& Anger) as $0.06 \mathrm{mg}$ per individual for $H$. ulvae and by means of the following regression equation for M. baltica:

$$
\log \mathrm{AFDW}=2.45 \log \mathrm{s}-4.59
$$

whereas AFDW $=$ ash-free dry weight $(\mathrm{mg}), \mathrm{s}=$ shell length $(\mathrm{mm})$. The sea-star abundance is fixed as $5, \mathrm{~m}^{-2}$.

According to this estimate, a single $A$. rubens ingests 1.9 to $11.4 \%$ of its own body mass (expressed as AFDW of the two main food items) daily, depending on its body size. A small amount contributed by other prey organisms has to be added, but is probably not important. These figures are very small: Thorson (1958) estimated the daily consumption rate to be at least 25-30\%. It cannot be determined at this time if our values used for the calculation are underestimated or if 'Thorson's estimate, which is based on older results (e.g. Galtsoff \& Loosanoff, 1939), is too high.

Thus, it is possible that the consumption rate of $23.5 \mathrm{mg}$ organic matter day $\mathrm{y} \mathrm{m}^{-2}$ for the total starfish population is too low. However, this value together with the actual starfish biomass of 300 to $700 \mathrm{mg}$ organic substance $\mathrm{m}^{-2}$ reveals that at least during the summer $A$. rubens plays an important role as a consumer and thus as a competitor to demersal fishes on soft bottoms of the western Baltic Sea. If one compares these estimates with those of Arntz (1971) for benthic production and further data on the consumption by exploited fish species (Arntz \& Brunswig, 1975), the presumption seems justified that $A$. rubens probably consumes more macrofaunal biomass than do commercially important fishes.

Acknowledgements. We are obliged to the company GKSS, Geesthacht (FRG), for working places in the UWL, and to the technical UWL-team for support and ccoperation. Our thanks are also due to Prof. Dr. W. Noodt for supporting the diver group at the Zoological Institute of the University Kiel, to Dr. J. Markham for correcting the manuscript, and to Frl. M. Grützmacher for identifying the algae. 


\section{LITERATURE CITED}

Arntz, W. E., 1971. Biomasse und Produktion des Makrobenthos in den tieferen Teilen der Kieler Bucht im Jahr 1968. Kieler Meeresforsch. 27, 36-72.

- \& Brunswig, D., 1975. An approach to estimating the production of macrobenthos and demersal fish in a Western Baltic Abra alba community. Merentutkimuslait. Havsforsk. Inst. Skr. Helsingfors 239, 195-205.

Brun, E., 1968. Extreme population density of the starfish Asterias rubens L. on a bed of Iceland scallop, Chlamys islandica (O. F. Müller). Astarte 32, 1-4.

Bull, H. O., 1934. Aquarium observations on the rate of growth and enemies of the common star-fish, Asterias rubens L. Rep. Dove mar. Lab. (Ser. 3) 2, 60-65.

Feder, H. \& Møller Christensen, A., 1966. Aspects of Asteroid biology In: Physiology of Echinodermata. Ed. by R. A. Boolootian. Interscience Publs., New York, 87-127.

Finnish IBP-PM Group 1969. Quantitative sampling equipment for the littoral benthos. Int. Revue ges. Hydrobiol. 54, 185-193.

Galtsoff, P. S. \& Loosanoff, V. L., 1939. Natural history and method of controlling the starfish (Asterias forbesi). Bull. Bur. Fish. Wash. 49, 73-132.

Hancodk, D. A., 1955. The feeding behaviour of starfish on Essex oyster beds. J. mar. biol. Ass. U.K. 34, 313-331.

- 1958. Notes on starfish on an Essex oyster bed. J. mar. biol. Ass. U.K. 37, 565-589.

Hatanaka, M. \& Kosaka, M., 1959. Biological studies on the population of the starfish, Asterias amurensis, in Sendai Bay. Tohoku J. agric. Res, 4, 159-178.

Kowalski, R., 1955. Untersuchungen zur Biologie des Seesterns Asterias rubens L. in Brackwasser. Kieler Meeresforsch. 11, 201-213.

Kühlmorgen-Hille, G., 1965. Qualitative und quantitative Veränderungen der Bodenfauna der Kieler Bucht in den Jahren 1953-1965. Kieler Meeresforsch. 21, 167-191.

Loosanoff, V. L., 1958. Underwater studies of starfish behavior and evaluation of control methods. Bull. Biol. Lab., Milford 22 (4), 1-5.

Muus, B. J., 1967. The fauna of Danish estuaries and lagoons. Meddr. Danm. Fisk. -og Havunders. 5, 1-316.

Paine, R. T., 1976. Size-limited predation: an observational and experimental approad with the Mytilus-Pisaster interaction. Ecology 57, 858-873.

Rogal, U., Anger, K., Schriever, G. \& Valentin, C. Quantitative macrobenthos studies in Lübeck Bay (western Baltic Sea). Helgoländer wiss. Meeresunters. (in press).

Sdulz, S., 1969. Das Makrobenthos der südlichen Beltsee (Mecklenburger Bucht und angrenzende Seegebiete). Beitr. Meeresk. 26, 21-46.

Smith, G. F. M., 1940. Factors limiting distribution and size in the starfish. J. Fish. Res. Bd Can. 5, 84-103.

Spärck, R., 1932. On the capability of migration of adult individuals of Asterias rubens. Rep. Dan. biol. Stn. 37, 65-68.

Thorson, G., 1957. Bottom communities. In: Treatise on marine ecology and paleoecology. Ed. by J. W. Hedgpeth. Geol. Soc. Am., New York, 1, 461-534. (Mem. geol. Soc. Am. 67.)

- 1958. Parallel level-bottom communities, their temperature adaptation, and their "balance" between predators and food animals. In: Perspectives in marine biology. Ed. by A. A. Buzzati-Traverso. Univ. Calif. Press, Berkeley, 67-86.

- 1964. Light as an ecological factor in the dispersal and settlement of larvae of marine bottom invertebrates. Ophelia 1, 167-208.

Tortonese, E., 1963. Differenziazone geografica e superspecie nel genere Asterias (Echinodermata). Monit. zool. ital. 70-71, 212-221.

Yoshida, M., 1966. Photosensitivity. In: Physiology of Echinodermata. Ed. by R. A. Boolootian. Interscience Publs., New York, 435-464.

First author's address: K. Anger

Biologische Anstalt Helgoland (Meeresstation)

D-2192 Helgoland

FRG 